\title{
Re- engineering education and development from the prevalence of system architecture of the social media network
}

\author{
Filibus Jamaka Auta \\ Department of Curriculum and Instructional Technology, \\ Federal College of Education (Tech.), Gombe, Gombe State, Nigeria
}

\begin{abstract}
This paper examines how four systems of re-engineering principles namely, complete operational process system, set-transformation system socio-technical system and technical/workflow environmental analysis re-engineering system, these systems have contributed to life-changing opportunities created by mobile and web-based digital telecommunication systems, the social media networks. The paper also highlighted the structure, functions, and transformation of the society resulting from cell phone design, social media simulation and modelling. They have not only contributed immensely in education and development, especially among the youth. Despite, the regulation policy of government, network providers, a whooping one hundred and sixty-four thousand, six hundred and forty-two subscribers in the year two thousand and thirteen, the number is still growing, are online for education and development. Subscribers are sometimes found on the contradictory side of social practice when they are suppose to confine to practice of environmental learning, distance learning, longlife learning, formal and informal education to avoid danger, restrictions contradictions, that had been the vision mission of the preceding mass media practice which has now exploded to a digital telecommunication broadband of the cell phones/satellite phones, popularly named the social media networks.
\end{abstract}

Keywords: social media networks; environmental learning; education; development

\section{INTRODUCTION}

Re-engineering in this context is a borrowed term and concept. In this it is an applied notion of reconstruction, revitalisation and energizing. The preponderance of humanistic activities, scenarios by increased performance from people in education and development lies the vision projected in this academic exercise or reportage, which the researcher intends.

In recent times, Nigeria speaks of transformation. Humanistic activities are echoing the same vision of re-invigorating a healthy, wealthy society. More of its actions have continued to demand for political transformation, economic transformation, cultural transformation, religious transformation and environmental transformation. The target is better equity of life achievable through social transformation. The process of social re-engineering and transformation as confined in education and development could seriously be aliened to a metamorphosis of conflicts, competition, assimilation, acculturation, accommodation, consensus, cooperation, specialization, differentiation and stratification. This is the position of 
Hogan, (2006) on social transformation. These observable behaviours and constructs have varying degrees and percentile landmarks on social, economic, political cultural, religious and environmental systems of a society.

The human factor is elemental in the formulation and operation of social media system architecture and policies. If a system is bad, the operator or the system itself is bad. Systems work coherently. The good aspects are capitalised upon for progress by closing loopholes and gabs. In this regard social media, national communication policy, technology policy be consolidated for the full benefits of the investments on infrastructure, technology, man power development and for re-engineering principles to accrue.

A literate population is an embodiment of creativity and innovation. Such a population will always encourage education and development. Education remains the pivot around which systems and the social network revolves. As a denominator it controls the policy, messages, professional and general development. The people should realise that knowledge is not only power, it is also wealth and health capable of re-engineering.

The political and economic power projected in a society can achieve stability through the social media, it can also revitalise, as network has duty to mobilise the society against ignorance superstition, disease and galvanise it to self sustaining development. It is wealthy, healthy and wishful thinking that all should expect the social media to help achieve national aspirations as content in the nation's constitution, social media national policy etc. We can also see that video, tapes, cables, television, computer games, provide cheap popular entertainments these have the power to divert people from more serious informational, educational, developmental messages to other competing attention etc.

The social media policy and national information management has been employed to safeguard and maintain national and international peace, resolutions and relations, this is critical in the face of recent terrorism. The social media in a controlled system should be a source of national pride, national security, territorial integrity, reprosity etc, so that the individuals, nations are not exposed to danger, restriction and contradiction. The operations of the social network suppose to be controlled. This should be the position of the legal environment. For example formal and informal censorship can lead to inefficiency, indiscipline, corruption and maladministration from censorship process. As laws are guiding principles involving everybody, there should be cooperation in the conduct of censorship. The interdependence of national and international organizations made the world a global village. The enhancement is social media activities. It is imperative for nations to strictly maintain social network policy, appreciate international development partners to manage social media against contradictions.

\section{SOCIAL MEDIA NETWORK A MOBILE AND WEB-BASED TECHNOLOGY COMBINATION}

A number of technology combined are responsible for operational success on the social media platform. Up mostly, social networks are carried on corporate utility of mobile and webbased technologies that create highly interactive forums, from which individuals, communities, organizations share, co-create, discuss and modify user-generated content.

Media professionals tend to look holistically at the social media in terms of infrastructural facilities, architecture, access methods, etc, these could be categorised as:

- physical and infrastructural facilities

- system architecture 
- integrated assistive technologies/devices

- corporate assistive technologies/devices

These categories can assume a more scientific arrangement based on reengineering concept of transformation, education and development. Also applicable to social network Oliver, (2006), suggested that reengineering or redefining process in a society could assume the following:

- Complete operational process system reengineering.

- Set-transformation system re-engineering.

- Socio-technical system re-engineering.

- technical and workflow environmental analysis re-engineering

\section{CONCEPTUALIZATION}

The social media is an integrate of modern digital communication, designed by a set of electronic tools that produce interaction and sharing from mobile and web-based applications. The communications modes hear are non-vocal communication, signals, signs, symbols, icons, gestures, proxemics and vocal communications. These are put to use by social media application of blogs, facebook, twitter, You tube, flicks, Linkedin, Yahoo, MySpace, Google, ConnectU, etc. From these people around the world are helped to establish and nurture relationships and to access high quality data, improve business decision making, increase total investments, accelerate economic, environmental and social impact from mobile and webbased solutions.

Before the digital era, we lacked publicly available data and analysis to support decision making and clarify socio-economic impact benefits, this situation created gabs and emptiness from multiple sources as World Bank, UN, operators, vendors and development organizations. Today, the interest in education has increased. The adoption of the social media rendered new skills, new capacities are emerging. Opportunities in education are closer than ever. This was accelerated by the freedom of information bill passed. The convenience of the social network as an educational tool is its ability to share knowledge. This has opened-up learning opportunity in our universities. Today, universities offer certificates, degrees and post-graduate programmes online. The barriers situation of the classroom system are now broken. New skills are developed online; other life-changing opportunities that had come to bear in education through social networks are research, globalization, mobilization, governance etc. These mechanisms had gone milestones to enhance changes in social, economic, political, cultural, religious and environmental orientation by extension.

Conditioning the mind is major influence of the social network. The process could be seen as a systematised reengineering on the audience and end-users. Matters concerning public opinion on political issues have tremendous influence on personal life-styles, tastes, consumer behaviour, sensitivities and disposition and possible inducement of violence. Therefore, change is synonymous to reconstruction, reengineering and imurnical to social media. It was a reengineering phenomenon that brought the age of mass media that saw the advent of books, newspapers, magazines, recordings, radio, movies, television, internet and analogue system. It was the mass media era that saw the world through a preceding information revolution. A remarkable reengineering process started with the explosion of the digital communication technology in the late 20 th century and early 21 st century. Humanistic interaction became more 
prominent by reconstructing entire human activity. For example the inclusion of cell phones, video games, computer games ignited reengineered a mind reeling communication platform.

Organizations, communities and individuals operating decently on the network are seen adopting a systematised management principle of prescription, development, implementation, institutionalization, monitoring, control and sustenance to avoid wrong use and contradictions. To give more credence, to this formation one can categorise and premise the structure as:

- complete system operational process re-engineering

- set-transformation re-engineering

- socio-technical system re-engineering

- technical/workflow environmental analysis reengineering

The social network in education has helped the academia with improved data for research. It has also opened opportunities to publish research. According to GSMA 2013, mobile for development, the mobile network, should make handy statistics on the following to facilitate socio-economic activities of elite and literate population:

- Children out of school

- Expenditure per student

- Gross domestic product (GDP) per person.GDP divided by total employment in the economy.

- Labour participation rate. All people who supply labour for the production of goods and services during a specified period.

- Literacy rate among adult and youth

- Pupil Teacher ratio

- Trained teachers.

- Total unemployment.

With these statistics on ground elite citizens are able to plan ahead.

\section{SOCIAL MEDIA DESIGN}

Social media a component of the modern communication satellite receive, amplify and transmit information back to the earth from the geosynchronous orbit, providing television, telefax, telephone, radio and digital data links around the world. Both connect users directly to the tele phone network from almost anywhere in the world. The design characteristics and function of the satellite raison the fact that the satellite:

- provide services more expensive than cellular services.

- give users access to the telephone network in areas of the world where wired or cellular telephone services exist.

- satellite phones like the social media are able to deliver video images through video phones that use tiny cameras and transmit there images via the satellite phone.

The social media therefore, has the potency of a telecommunication system and network. Its tele communication outfit means the social media network are devices, systems that can transmit electronic or optical signals across long distances. Its added value and use is for long distance communication process. The elegant, technique, pattern, shape, geometric art of design of the telegraph, telephone, teletype, telex and facsimile transmission, radio, television, global positioning and navigation systems, personal computers and voice over internet protocol(VOIP) are a display of skilful and artistic talents in the manufacturing to send 
information to distant places. The plan portrayed in the form or structure emphasise its appearance, convenience and efficient function.

The consequence of these is the emerging manufacturer's trends. By 2005, Apple computers had 100 retail outlets in US, Canada, Japan, the UK. This grand achievement saw it through a pioneering music services. As time goes on, when it unveiled the Ipad nano, that was smaller thinner version, it sold about 39 million pieces. And soon realise that users had download more than 2 billion songs from its music store in 2006. Building on the success already recorded, Apple diversify its products line. In 2007 it renamed Apple incorporation. Before 2007 other manufacturers had pioneered the production of Smartphone, Apple followed in January 2007 to develop the Iphone, with cell phone capable of playing music, video, surfing the web and sending e-mail, making telephone calls. The product was popular for its unique graphical user interface design which included touch screen capability, instead of a built in keyboard. The Iphone has a single carrier, single wireless, offer search function with special application from Google and yahoo. Other design characteristics and functions introduced are:

- television, a digital video system, plugs in to a television set, stores up to 50 hours of video

- Wireless transfer of video from computer to television set

- Cell phone (cellular radio telephones) combined radio with wired or wired-based telephone network users to access all public telephone system used by non-mobile callers

- modern cellular phones use a network of short range antenna, to towers that connect to the telephone systems. Antenna is shorter range covering 1.5 to $2.4 \mathrm{~km}$ with 1.0 to 1.5 MI frequencies and can be reused without interference. The satellite phone and cellular phone deliver video, music, images via tiny cameras. Here the excitement, anxiety is much. This is where high density users lie and tend to permit intercultural contacts, cause economic, political, social, doctrinal, commercial rivalries are clustered, leading to wrong use of social media in violation of privacy, moral decadence, cyber crimes etc.

\section{SOCIAL MEDIA MODELLING}

Thompson (2009) said that social and emotional development raise on relationships. He added that growth of social skills and social understanding, with influence of the world on emotional lifestyle frames and stems the type of social relationship that is established. Therefore, relationship begin with an attachment and develops through caregivers role models, it expands with growth of relationships. For example, an expansion from romantic relationship to marriage relationship to care/rearing relationship and to friendship in the workplaces and other congregational forums of intra persons relationships. The people's social world is made of parents, relatives, friends and others, help to shape, fashion emotional life of individuals.

Within the social world are politicians, economists, engineers, culturalists, educationists, philosophers, etc, these are role models. A thematic essay (2009) pinpoint that political thought of government has as its cardinal focus respect for the rule of law and rejection of arbitrary and despotic authority must be rooted. Furthermore, that peaceful and revolutionary reforms as opposed to violent revolutionary change, respect for individual right are the basic notions of liberty, human right and conservativeness. Robbs (2009) stated on interactive television, access to high speed transmission over cable lines or optical fibres enable consumers to select from a vast video library. Multimedia can make learning easier and more fun, click a little in the list 
to open a media item such as a photo, audio clip, video or illustration, these have modelling capacity.

The Cambridge of Idioms (1999) has that model is something accepted to be an excellent example of fashion. On the other hand, fashion is a form of behaviour that is socially approved at a given time. This is a more literary meaning of fashion against its novel idea of clothes. Ramalingam (2006) and Hogan (2006) agreed that fashion is a social convention, characterised by, it changing a competitive character in areas of interior decoration, architecture, forms of entertainment, social behaviour, automobile models even breeds of dogs. Providers of GSM services of the social media have joined in the forefront of modelling. The social media, now littered in the society is a fashion, a convention of the time modelling the society.

Every man is born creative. There is creativity of design in every human. Designers have won laurels in organised competitions severally in their unique styles, base on quality of fitness, order, beauty, excellence of style that synchronise the thinking of the time. They demonstrate a way of behaviour so that the behaviour is imitated. They have raised the fashion capital and convention by increased used of technologies, the social media, in industrial, economic situation, lifestyle changes and modelling. Important events in the society change people's everyday ways of living, this may also influence the style of the time. At various levels of social convention fashion, book, plays, motion pictures and well known people, celebrities have given rise to new conventions and modelling.

When the social class gain patron, gain nobility, become wealthy, powerful, men women symbolise the leading convention and become arbiter of styles. Symbol of international success, provide a sense of exclusivity, draw lavished attention, with opulent designs accessories, become public image in established pattern of contemporary that occupy the centre stage, events and influences contribute to popularity of various ' looks', modelling and fashion. Soon after more women got attracted into industrial work, business, rationing effects on manufacturing simple wears that give greater freedom, simple to maintain. These wears permit safer movement, safer for sports activities. The wears were won to workplaces and industries that set a convention. Modelling also became popular amongst youths. At the period of reconstruction affluent youths made less formal, less rigid, less expensive fashions.

These exerted revolutionary influence on conventions at that time. Social organization that simulate conventions and modeling a society are:

- cultural position of women and ethnic group gender consideration

- economic expansion trend within creased purchasing power and poverty reduction

- technologies influencing mass production in production industry.

- Advertisement on the media, political advertisement, and cultural impact advertisement

- Influence of television and internet, photography

- film, television show, music video, live performances, newspapers, magazines, radio, television

- association modelling; blue jeans working class association, etc.

\section{SOCIAL MEDIA SIMULATION}

Burnie (2009) and Encyclopaedia Britannica (2010) agree that human behaviour are conditioned by interactions among persons and group. The social media has that capacity. Therefore, the interaction, the conditioning, the reengineering, of experiences, the simulation by individuals and groups in customs, traditions, pattern of historical development and social 
institutions such as marriage, family, ways of holding property, educational arrangement, government and legal system can translate behaviour patterns that are distinct characteristics the social media is playing the run.

The constitution stands as essential feature of political, social, economic thoughts of a society. Human society the past, the present and the way human beings behave could be explored from the way society is structured, functions combine with individual behaviour and the mind. These are the thoughts of Brunie. He added that the influence on people's behaviour and attitudes left much to question on politics, socialization, law, economics, ecology, stock market and global corporation that are human and non-human concepts, which help to picture people's behaviour. Such human efforts transcend to presentation of laws, constitution, policies, as essential elements of control philosophy of a society, as provided by the social media.

Scientific knowledge developed is harness for practical and useful ends. Knowledge of science and practical ends are chiefly from mathematics and the physical sciences applied in designing machinery, materials and industrial processes recognise as engineering. The social media network repeatedly in use will propel a simulation towards real developmental activity in a society, as experience is a teacher.

Observation is one of the methods of analysis not restricted to large social groups or subgroups. But also focus on small units as well, as small as the family. Smaller units have a lot to offer in analysis of social media and society; in poverty, religion, the working class, women immigrants, ethnic groups, teenagers, criminals etc. On the accounts of their distinctive customs and interaction, we seek to describe and explain behaviour of the people, how they differ, similar or varying levels of productivity, attitudes to work, in workplaces, cause of social change, social media how an instrument for the improvement of human environment. For sometimes much observation on individual behaviour in social and cultural setting vis-à-vis the adoption of the social media, the concern have been the effects of social media on personality, motivation and attitudes of individuals. The computer game, cybernetics have attributes that simulate real activity in engineering, vocabulary development. Recurring question is how are youths affected by the social media? What is the mental, emotional impact of the social media? What are the political effects and social attitudes developed from social media?

\section{EDUCATIONAL RE-ENGINEERING}

In uptime recognition and appreciation of the pervading power of the social media, it is observed that every person, group, community or organization is in touch with the world at all times. The network is revitalising, re-engineering the people to a globalization mood in communication. The experience, is prominent in formal and informal curriculum, as itemised in the reengineering idea.

\section{1. Complete operational process re-engineering}

The social media is conscripted by policy frameworks that premise educational initiatives, educational incentives, and strategies that could enhance programme implementation by extension. Generating such formal and informal curriculum would attest to system architecture of the social media, which encompasses acquisition, mergers, collaboration, transformation, corporation, initiatives, networking, globalization, short term and long term planning. At initial stage the strategies include:- planning, prescriptions, 
development of plans, implementation of plans, domestication of such plans and curriculum by institutionalization to realise the goals and vision of education. It is obvious that re-engineering will requires a host of strategies. Educational opportunities must be at the forefront in order to improve over all performance. Related to these a team of experts in conjunction with stakeholders may be designed in a way to realise optimum performance of the curriculum. The planning, prescription, development and implementation are conveyed through attributes of activities, resources and communications.

Alternative design options are produced through brainstorming, innovation and creativity to meet objectives, to engage human resources and system architecture for smooth transition. Unskilled members may require training from which more jobs are created leading to sound change techniques of a successful migration. Here roles adopted, causes of problems, nonvalue adding activities are identified, cost benefits are analysed, closely monitored in order to compare success registered between old and new educational needs. The monitoring of old and new process will ascertain effectiveness of structural change of the complete operational process reengineering, to meet objectives, goals, affirm quality of change in formal and informal curriculum.

\section{2. Set-transformation reengineering}

We are aware of the pivotal roles of education in its ramification. We are also mindful of Nigeria's economic transition, which shows a departure from mineral exploration to more productive export-oriented economic development. Empirical analysis showed that organization desire to occupy political and economic space. The consequence is that such organization set achievable targets in order to be on the high side. Youths are large fragment of the population. Today, the youth are clamouring for high levels. Despite internal and external interference, agents and organizations struggle at all odds to wave away such interference on account of objectives and implementation. Relevant question on this is, are the problems emanating from the network or web-based. Most often members are retrained to acquire new skills. Some are fittingly converted to new system. The prelaunch of old practices found adaptable in the new system, assist to transform and are eventually domesticated and institutionalised. The social media for education has helped provide the academia with improved data for academic search as:

- teachers use infinite Google drawings to create visuals for their classrooms. This is socio-technical reengineering as teacher hopes to stay on the job

- They also use Google drive to add both text and voice commends for sharing audio as well as written feedback with students. This is modification by set transformation.

- Ipad applications and resources help students in their writing skills to improve their writing style. This relates to socio-technical re-engineering.

- Six web tools are used to edit pictures for use with students. Pictures are adjusted to required level before being taken to class. This is an element of technical/workflow environmental analysis reengineering.

- Ipad resources, Google resources, facebook resources, android applications, Smartphone applications are available, networked to other social media, email, twitter etc with infinite applications. This is both socio-technical reengineering and technical workflow environmental analysis. 


\section{3. Socio-technical system reengineering}

However, the nexus between modifying factors embedded in the social network is the range of application including menu, icons, online, links, email, websites, downloads, to sharing, digitization, extra-views, multi-choice interaction, control and sustenance. Social organizations such as educational institution, socio-economic institution, religious institutions, political institutions, are being transformed, reengineered, revitalised as a result of new technical system. A case in point is that, banks laid off many of their staff. They were not computer literate. Damaging result came as a result of changes in technology. Technology has cause lack of employment, as members became unskilled with new technology. The ambition to occupy higher levels made old systems to be rationalised also causing unemployment. Vices may take its natural course as people are setback, workers are dropped.

That the social media network is a reservoir of knowledge that are shared globally is obvious. The digital communication network is finally here. Other life-changing opportunities emerging from the social media are:-businesses, e-banking, market and advertising, consumer protection, research, globalization of practices, employment generation, virtual office, public governance, political mobilization, social mobilization, tele-medicine, global integration. Professionals are equipped with new skills to remain relevant.

\section{4. Technical/workflow environmental analysis reengineering}

Furthermore, it is not out of place that education has received considerable boost on the social media. New capacities have emerged from new technologies. For example, municipal governments now rely on information system of population density, weather forecast to provide basic services to citizens. Individuals use information systems to study, shop, bank, invest, share, produce and distribute. Opportunities in education are made handy by the social network. As a convenient tool it receives impact and share knowledge. A striking enhancement in education is that universities all over award certificates, degrees, postgraduate programmes, run strictly online. This development has simply broken geographical barriers of high cost in the traditional classroom process by providing quality education online.

\section{DEVELOPMENTAL RE-ENGINEERING}

Since man realised it was possible for him to control not only the physical world for social ends but also the social world for social ends. Man has seized to stop at nothing than to employ various means including the social media components, it's system architecture in order to better develop his information communication system. This is emphatic individual development compared to the mass media age and its paradigm shifts.

Okenwa, (2013) presented the valued added services rendered by a comprehensive statutory social media network provider, named CyberSpace network limited, located in Lagos. The services of organization include:- SMS to email, package tracks, school results checker, text to TV scroll, flight schedule services, lottery game playing, SMS message broadcasting, financial messaging gateway, payment transaction, exam registration, picture message, downloads, real estate, voting services, database transaction monitoring with alert, ringtone, vas gateway, mobile news. This can be considered a jumbo harvest of re-engineering structures. And it can represent complete operational process system re-engineering and sociotechnical system re-engineering when infrastructure, system architecture are involved. 
Life changes are matter of constant and continuous modification of experiences. Change remains a driving force in re-engineering. Development synchronises change. Since ideas change, attitudes and skills undergo alterations in this case prompted by new technologies, infrastructure, facilities, system architecture. The new technologies are enormous. With prominent training and practice, change attitude and revitalization in education and development are possible. At present almost every one's mind is bombarded daily by far more social media symbols and messages that the human organism can possibly pay attention to. This mind blowing communication outfit can relate to socio-technical system re- engineering, technical/workflow environmental analysis re- engineering, set-transformation reengineering.

To enjoy these technologies and to remain relevant, one needs to constantly finance change and opportunities that occur. It is common feature that the total subscriber base kept raising. The number of phone lines per 100 of population has continually increased. Okeke, (2013) reported that a teledensity of 40 and 50 per population is pretty good density. He added that official records stated that Nigeria has a teledensity of 85.97 million as at June 2013. This development is against teledensity of 80 million in September,2010. The subscriber base is astronomical, on the rise. We registered a subscriber base of 148.161 million as of April, 2013. These suddenly rouse to 164.642 million as at June, 2013. It is also a welcome development that a subscriber willingly retains his mobile phone number when he eventually switches to another service provider. This practice is called Mobile Number Portability. The experience here is no other than socio-technical system re- engineering for development.

The Mobile Number Portability remains a key facilitator for consumer choice, effective competition in the telecommunication environment and checking deactivation laws which disallowed full access to networks. It was also recorded that the gain accrued to network providers of Airtel, Etisalat, Globacom, and MTN. were impressive. By june, 2013, airtel had $50 \%$ gain, while etisalat had $29 \%$ gain, and globacom had $17 \%$ gain in may 2013 . This could be seen as set-transformation re- engineering. On the occasion of technical and workflow environmental analysis re- engineering the network providers embarked on expansion programmes. MTN had a consortium of banks jointly giving it three billion naira for network expansion. Globacomm earmarked 1.75 billion for service modernization and capacity expansion. On the other hand Etisalat had 1.2 billion for network capacity expansion. What a superfluous re-engineering effort. The added valued services here will ascend as a result of the expansions. These would boost socio-technical system re-engineering and others.

The euphoria in the mobile network has already brought a communication industrial overload, resulting in the alienation of millions of people from much of modern life is expected to reach even higher levels in the coming generations, as still higher densities of population, intercultural contacts, communication facilities causing economic, doctrinal and commercial rivalries to still be more intense.

\section{CONCLUSION}

Believe in your abilities as much as you believe in yourself. There is no limit to what you can achieve. The sky is wide enough for the birds to fly without collision. The social network is big enough to accommodate all of us. The non-vocal communication, signals, signs, symbols, icons, gestures, proxemics and vocal communication types are now digitalised with extraviews, sharing, placed on multi-choice contacts and fixed on infinitives, broadband of the social media. The effect is that the mind reels under noisy assortments of information bit about rival 
politicians, rival political programmes and doctrines, new technical discoveries insistently advertised commercial products, new views on morality, ecological horrors and military nightmares. However, these remains under checks and balance of regulatory policy of government but educational strives and developmental strikes are enormous calling for purposive change of individual, community or organization.

\section{Recommendations}

1. Regulatory policy of government has a remarkable influence on the use of the social media network. The policy should entail control on the number of lines individuals should have or possess. There should be restriction policy on network providers who are directly link to end users in terms of charging, clustered promo SMS and advertising. Service providers should keep to terms of contract agreement by rendering valued added services according to best practices. The control should be extended to take charge of and control the wrong use of social networks.

2. The propensity and prevalence of the young at heart to access new views on morality, horrors, and night mares from different cultures should constantly be checked and possibly blocked. These can possibly generate and translate violence, information that could cause transformation of negative behaviour and infringement on privacy. More to that, youth are the most vulnerable. They are prone to pornography, cyber violence, violation of privacy, etc. For the social network to be more productive they should be configured to serve as skill acquisition outfit as while as entrepreneurial development forums and networks. In addition the present operations of the social networks can properly be monitored to ensure that individuals, communities, organizations play safe according to the rules of the game to avoid contradictions.

3. Since a large population is captured on a network, it becomes rowdy, control and order becomes difficult and complex. A whooping 164, 642million subscribers on the network is a large figure, the set- transformational process, the operational process, socio-technical process, technical workflow environmental analysis should be systematised to ensure smooth reengineering culture in human capital development.

4. Database information systems should promptly placed on the networks. Statistical data are very important assistance in research. Numerical information, educational statistics and database development issues have authenticate research findings in education. Access carriers be developed maintained and made available and handy.

5. Youths are the most vulnerable when it comes to the negative use of the social media. The Cynthia case is still fresh in our memory. It was online friendship that caused her life. The euphoria of friendship online can turn sour. It is dangerous for one to disclose his personal details such as contact address, number and pin number to friends and strangers on the social network. In addition the social media has assisted a lot. The government, NGOs, youth based organizations and other relevant stakeholders should properly harness the social media along positive line for human capital development, so that they will tools for societal integration. 


\section{References}

[1] Apple corporation (2009). Apple incorporated Microsoft Encarta, 2009 DVD, Remond, W. A. Microsoft corporation, 2008.

[2] Burnie D. (cbn) (2009). 'Science', Microsoft Encarta 2009 DVD, Remond W.A. Microsoft corporation.

[3] Broadband Technology (2010). Encyclopaedia Britannica, Encyclopaedia Britannica student and home-edition, Chicago; Encyclopaedia Britannica.

[4] Cambridge dictionary of idioms (1998). Cambridge international dictionary of idioms, Cambridge university press, Cambridge, United Kingdom.

[5] Computer and information systems (2010). Encyclopaedia Britannica, Encyclopaedia Britannica student and home-edition. Chicago, Encyclopaedia Britannica.

[6] Darpa-50 years of innovation (2010). Encyclopaedia Britannica, Encyclopaedia Britannica student and home-edition. Chicago, Encyclopaedia Britannica.

[7] Encyclopaedia Britannica (2010).Fashion, Britannic student article. Chicago, Encyclopaedia Britannica.

[8] Encyclopaedia Britannica (2010). Sociology, Britannica student article. Chicago, Encyclopaedia Britannica

[9] Hogan M. O.2006). Academic's dictionary of sociology. Academic publishers. New Delhi, India.

[10] Obi G. (2008). Information technology governance: imperative of emerging economy. The Nigeria accountant, January/march, 2008.

[11] Okeke M. (2013). Periscope: Nigeria; figure highlight strong economy. Zenith economic quarterly July, 2013.

[12] Robbs B. (rvd) (2009). 'Advertizing', Microsoft Encarta 2009 DVD, Remond, W. A. Microsoft corporation.2008.

[13] Propaganda, (2010). Encyclopaedia Britannica, Encyclopaedia Britannica student and home edition. Chicago, Encyclopaedia Britannica.

[14] Ramalingam P. (2006). Academic's dictionary of psychology. Academic publishers, New Delhi India.

[15] Sampson E. (2013). Social media: the good, the bad, the opportunities. Zenith economic quarterly July, 2013.

[16] Thompson R. A. (2009). 'Development psychology,' Microsoft Encarta 2009 DVD, Remond, W.A. Microsoft corporation.

[17] Thematic Essay (2009). British political and social thought, Microsoft Encarta 2009 DVD Remond, W. A. Microsoft corporation. 2008.

[18] Inuwa Abdu Ibrahim, International Letters of Social and Humanistic Sciences 8(1) (2014) 34-39.

[19] Nneka Rita Udoye, Victor Etim Ndum, International Letters of Social and Humanistic Sciences 8(2) (2014) 130-139. 
[20] Juliana A. Oboniye, International Letters of Social and Humanistic Sciences 8(2) (2014) 158-169.

[21] David Ifeanyi Okoli, Emmanuel Ifeanyi Okoli, International Letters of Social and Humanistic Sciences 8(3) (2014) 224-233.

[22] Fowoyo Joseph Taiwo, International Letters of Social and Humanistic Sciences 8(3) (2014) 244-251.

[23] Jackson Omasanjuwa Ireyefoju, Florence Ejuogharanmakelesan Ireyefoju, International Letters of Social and Humanistic Sciences 10(1) (2014) 62-68.

[24] Adjekophori Bernard, International Letters of Social and Humanistic Sciences 12 (2014) 23-40.

[25] Martins Iyoboyi, International Letters of Social and Humanistic Sciences 16(2) (2014) 202-214. 